\title{
You Stole My Life, Jill Whelan
}

BERKELEY, CALIFORNIA, 1978.

Mom tells my sister Elena and me that she's entered us in a contest. She says the winner joins The Love Boat cast as the son or daughter of Captain Stubing. We don't have a TV, but every chance we get Elena and I watch The Love Boat and Fantasy Island on Saturday nights. I'm nine years old and Elena's five. We have no idea these shows represent some of the cheesiest moments in television history. We talk friends, neighbors, and baby sitters into this two-hour commitment. We're persuasive, or, maybe, just pathetic.

The information I've amassed is sketchy-bits and pieces of data plucked from cyberspace, public and university libraries, memory. Here's what I think: the actress Jill Whelan is a thief. Here's what I know for certain: she entered this world on 29 September 1966 by way of Oakland, California; her appearance in an M\&M commercial caught the eyes of Love Boat producers and got her cast on the show at age eleven; she appeared in 188 episodes, not counting the reunion shows; she won two Young Artist Awards-one for the TV movie Babies Making Babies and one for the Boat-and they nominated her for five more (Boat performances and a nod for Airplane); she made numerous guest appearances on other television shows; she sang for the Reagans at the White House; as an adult she designs jewelry, and her newest line, "The Bon Voyage Collection: Resort Wear Jewelry for the Seasoned Traveler," debuted recently, retailing through America's Collectibles Network, Inc. (a letter of endorsement from Whelan graces the website; if you plug "acntv" into an internet search engine, there are posts of complaints about ACN's advertising scruples and the quality of their goods; there are posts from satisfied customers as well); she's a motivational lecturer/keynote speaker, represented by the Premiere Speakers Bureau, and her reported fee is $\$ 10,000$ per engagement.

Mom and Dad divorce in '74, and, for the first four years, they send Elena and me bouncing between them like ping-pong balls: 
San Francisco; Stockton; Sacramento; Mendocino; Elk; Albion; the Mojave Desert; Claremont; Pomona; Berkeley. They move all over California, trying to figure out what to do with new, solitary lives. Mom drops out of a masters program in education. Dad ends up studying to be an architect in southern California. I'm not sure why we spend the next few years in Berkeley with Mom. Maybe they realized that eight elementary schools in four years can be disconcerting, so perhaps going for ten or fifteen in six isn't the best idea. In any event, Dad ceases to be a physical presence. He's incorporeal, a voice on a telephone.

Mom is thirty-five years old. She's a lithe five foot eight. Her face stands out amidst long dark hair, a bronze oval dominated by wounded, coffee-colored eyes. Sometimes, when she looks at me, I feel like I'm the only person on earth. Sometimes, when she looks at me, I'm terrified, waiting for her to lose it.

When she's happy we play games, read books together, bake desserts. We go on walks. She takes us to museums and art exhibits. We can't have dogs or cats in the apartment, so Mom gets me a snake and Elena a rat. I name my snake T.D., after the Great Brain. Elena calls her rat Rooskie. "They can never be out of their cages at the same time," Mom says, grasping us by the shoulders and looking us in the eyes. After feeding a couple of mice to my snake, we grasp the potential for tragedy.

Mom hits herself when she's really mad. She screams and slaps herself in the face, calls herself names. She doesn't hit Elena and me. When she's angry with us she remains icy and silent, ignores us when we try and talk to her, slams her bedroom door in our faces, doesn't come out for hours.

Men watch Mom in public. I notice them on the street, in bookstores, everywhere we go. Most do it on the sly, but every so often one levels a brazen stare. She seems not to notice. I don't understand why they're looking, but it doesn't feel right.

Every day I pester Mom with questions about the contest: when will we find out? How will they announce it? What's Hollywood like? She tells me to be patient and not to get my hopes too high.

Whelan first appeared on The Love Boat in episode 33. It aired November 4, 1978. The storyline had her as Captain Stubing's illegitimate daughter by a former girlfriend. She was obliged to wait 
one year and six days before returning to the show for good, in the same role, on episode 62 . With the exception of 65 , which may have been filmed prior to her hiring, she appeared in every successive episode of the original series.

THE CARIBBEAN; AN ISLAND IN THE SOUTH PACIFIC; THE FAR REACHES OF SPACE, 1978.

Every night, lying in bed, I imagine myself to sleep. I walk the decks of the Pacific Princess, the jungles of Fantasy Island, and the corridors of the Battlestar Galactica. For thirty or so minutes I inhabit an alternate unreality, as created by Aaron Spelling and Glen A. Larson. Most often I'm on the Boat, helping my dad, the Captain, see to the needs of his passengers and crew. Dad's a busy man, and sometimes I get shortchanged in the attention department, but it's okay because I have Doc, Isaac, Gopher, and Julie as surrogate uncles and aunt, always ready to dote and coddle. These fantasies never extend to a life outside the invented one. I'm never an actor on a television show. I'm always a boy in a crisp white uniform, surrounded by an adoring family, on a course for adventure, my mind on a new romance.

Mom, Elena, and I live on the third floor of a beige stucco four-story apartment building. It stands just off Telegraph Avenue on Dwight, three blocks from UC Berkeley, my Mom and Dad's alma mater.

I stalk Telegraph during the day, weaving between throngs of people, watching the sidewalks for change. It's July, and the sun shines hot on my shoulders. I marvel at the diverse characters swishing past. I see moccasins and tie-dyes, leather jackets and motorcycle boots, Mohawks and Chuck Taylors, loafers and corduroy sports jackets. The street vendors pitch passersby, lauding their jewelry and assorted arts and crafts, and everyone's chatter mixes with car horns and revving engines. Pungent clouds of tobacco and incense smoke hit me in the face.

I wander in and out of record and comic book stores. I sit for hours on the floor of Comix \& Comix and read Tintin, Asterix, and Willy $\&$ Wanda. Men with long, swinging dreadlocks, pointy beards, baggy, multicolored clothes, and tattoos on their arms chase me out of head shops. I can't understand why I'm not allowed in those stores, don't understand their significance, but forests of colored 
glass, gnarled like tree roots, keep me coming back, risking the wrath of hippies.

There are some great record stores on the Ave, but Rasputin's is the hippest. I like their used prices, but sometimes you pay in other ways. I have to take a record back three times because of skips, and, finally, give up and live with it. Later, in the interests of a good story that reflects well on me, I'll want it to be something cool like Ramones or X's Los Angeles (even though Los Angeles won't come out until 1980), but I'm nine, and I like this Tubes song, and it's only available on one album, and that album is the Xanadu movie soundtrack. It's excruciating to think that, not only do I walk into a store, rummage about, and end up at the counter with the Xanadu movie soundtrack in my hand, but I then go back three times and exchange it—not for a different, great record-but for itself.

Mom manages our apartment building. She's responsible for the sixty units, their upkeep and rents. We can't afford daycare after school or in the summers, so this job is the next best thing, allowing her to be around some of the time. I spend much of the day unsupervised. When I'm not on the Ave, I prowl the building with my friend Tran. He's Vietnamese, and his spiked, black hair and torn, khaki clothes scream cool. We like the back elevator because the emergency alarm doesn't work, so you can stop the thing anywhere, pry the doors open between floors, end up eye level with the ground, staring down hallway baseboards, shooting at each other from a mechanical foxhole.

We call the second floor the Creepy Floor. Dingy, yellow walls and red, loop pile carpet, pockmarked with cigarette burns, stretch the length of the back hall. Second floor people don't look up when you pass them, don't say hello. Bloated, salmon-colored tampons and tied off condoms sit, strewn along the hall. The condoms are wrinkled and translucent, gelatinous, like jaundiced jellyfish on a crimson beach. I don't know what they are. When Tran sees them, he laughs.

"What?" I ask.

He nods and says, "Yum."

Mom tries to augment her income by selling Fuller Brush products on the side. Our living room becomes a staging area, taken over by 
rows of brooms, brushes, carpet sweepers, and cleaning solutions. She spends evenings on the telephone, cold-calling numbers out of the phone book.

Mom always enrolls us in good schools, even if she has to pull address shenanigans to get around geographical district restrictions. Elena and I don't know we're poor, exactly, but we can tell we're different from most of our friends' families. They tend to live on high ground in large houses with vast lawns and plenty of landscaping. We're always ascending to see our friends and descending to return home. I will find out years later that one of my teachers, during a conference with Mom, offered to buy me a pair of shoes.

During the summer, Mom sends me to soccer and tennis camps. She sends Elena to Moochie Ubu, an upscale nature retreat for kids. We take this for granted, happy to be participating in the same activities as our friends. We feel a part of a community, until it's time to go home.

Between camps, she puts us in classes at the Lawrence Hall of Science. It sits on a hill that overlooks the UC campus. They offer all manner of science-based educational courses for kids over the summer. As an adult, I will wonder how on earth she paid for these things.

Early on, Whelan parlayed her quick show biz start into additional TV and movie roles. From 1978 to 1987 she enjoyed professional accolades and demands for her services. She was a media darling. Along with her regular gig on the Boat, she appeared as a guest star on Fantasy Island (twice); Vega\$; Trapper John, M.D.; Matt Houston; Battle of the Network Stars; Divorce Court; and The Law and Harry McGraw. She did TV movies. She also landed the I.V. Girl part in Airplane. She surveyed the world from a luminous, giddy height. Her possibilities must have seemed limitless. They sure looked limitless to me.

Mom's friend Rosemary lives in the building. She wears tight, earthtoned corduroys that flare at the ankle, home-dyed shirts, and highheeled leather sandals. She smells musky up close, a combination of sweat, smoke, and perfume. The crimson rose tattoo above her right breast stands out against chestnut skin and Joni Mitchell-colored hair. Most of her shirts leave the bud of the rose exposed, but the 
green, thorny stem disappears into cloth recesses, and I never do get to see where it ends, though I desperately want to.

I look for Mom one afternoon after school. I leave our apartment, walk down the hall to Rosemary's, push at the front door. It swings open and there's Rosemary, bending over a coffee table, her left hand holding a short straw between her nose and the table top, her right hand behind her head-as if she's about to be handcuffed-keeping her hair out of the way. Mom sits on the couch next to her. She turns and sees me, says, "I'll be home in a minute," and swings the door shut.

One day Rosemary stops coming around, and Mom doesn't mention her anymore. I wonder why they stopped being friends, but I'm afraid to ask. Sometimes Mom flips at little things, and we never know what'll set her off. I see Rosemary around the building for a couple of weeks. She doesn't speak to me. I don't see her after that. Years later, Mom will tell me that she caught her in our apartment, stealing jewelry.

Mom takes me down on the Ave, tells me we need to get a birthday present for Uncle Art, my dad's brother. He plays jazz piano and lives in San Francisco. She marches right into one of the head shops I'm always getting kicked out of and starts looking around. The cloying smell of incense almost makes me gag. I stay beside Mom, a satisfied smile of immunity on my face, and steal glances at the hippie behind the counter. He's wearing sky blue pants, a white T-shirt, and his dreadlocks are tucked under a brown wool cap, causing it to bulge irregularly, like a sack of potatoes. When he sees me, his eyes narrow above his stringy beard, and I grab Mom's sleeve and hold on, trailing behind her, a look of what I hope is innocence on my face.

Mom makes it to the glass display case that serves as a counter and asks Potato Sack if she can see several rectangular mirrors. He doesn't answer, just pulls them from the case and lays them on the glass countertop. Mom clasps her hands behind her back, bends at the waist, and her hair swings out on either side of her face, forming two brown curtains. She looks down on the goods with an air of supercilious gravity, as if she's facing a monumental decision involving thousands of lives and millions of dollars.

"That one," she says, pointing. "Perfect." 
Potato Sack scoops up the middle mirror, wraps it in purple tissue paper, throws it in a white bag, and rings it up. I pester Mom, but she waits until we're back in the apartment before she pulls it out, unwraps it, and hands it to me. It's done up in green outlines as mock currency. It has numbers on the corners and four machined grooves on either side of the face in the middle. Across the bottom it reads: "The Delighted State of America." I laugh and say, "Cool." I have no idea what it's for.

Mom gets a look in her eyes just before she goes over the edge. They open wider and seem to go into a long distance focus. It doesn't matter if she's looking right at me, I get the sense she's somewhere else, maybe trapped in a memory compartment in her brain, and not the one that houses the good times, either.

It's dark, and we're driving down a big avenue in our orange Volkswagen Beetle, heading for home. I can't see Mom's eyes right now, but I know she's got the look because she won't answer questions or acknowledge us in any way. Her head and arms engage in vehement jerks as she checks traffic over her shoulder, shifts gears, and changes lanes. Elena and I sit still in the backseat, breathing shallow. Mom steps hard on the gas and the car lurches forward. Elena grabs my arm with both hands. Mom guns it to a scream, shoves the gearshift into third. I hear the cogs grind and catch. She revs up again and throws it in fourth, popping the clutch so the car stutters then lurches forward. Elena's fingers dig into my skin, and I know her eyes are shut tight. The acrid smell of burning clutch sticks in my nostrils, so strong I can almost taste it. I'm frozen in terror. I have to watch. I peer over Mom's shoulder at the escalating speedometer: $40 \ldots 45 \ldots 50 \ldots 55 \ldots 60 \ldots 65 \ldots$ I stare out the windshield and can't believe our lane is clear. Gas stations and storefronts sprint by us, rushing in the other direction. The engine whines as we hurtle along. Cars zip by on either side-whether they're traveling with us or in the opposite direction, we tear past them. I can't believe we haven't hit a red light. Mom grips the wheel with white knuckles. She's hunched forward, breathing heavy, staring into the night. Oncoming headlights, traffic lights, streetlights, store lights, they all seem to elongate, blur, mesh together in a smear of color. A noise bursts from Mom's throat, an inarticulate scream composed 
of equal parts despair and hatred. She lets her foot off the gas, and the car coasts: $60 \ldots 55 \ldots 50 \ldots 45 \ldots 40 \ldots 35 \ldots 30 \ldots$

Regarding Whelan's casting on The Love Boat, I was unable to locate any information relating to a contest. From all accounts, national commercials got her noticed. She reportedly, of her own accord, sent one of her school pictures to a Bay Area talent agency, and this resulted in the landing of professional representation. The commercials followed. I can't explain this definitively, but I have several working theories:

One: Mom lied about the contest.

Two: My subconscious invented the whole thing.

Three: The contest was a scam, a disingenuous promotion by some company to make a fast buck.

Four: Whelan, being possessed of an unseemly and unhealthy drive and enthusiasm that bordered on psychosis, began her Anthony Robbins-esque drive for success at age eight. This mental aberration manifested in musical theater performances, her crowning as California Little Miss, and the launch of a professional acting career. Her megalomaniacal personality-in-the-making and budding connections within the entertainment industry then combined in skullduggery to subvert the Love Boat casting process, and a wouldbe legitimate contest winner got cheated out of their just desserts.

Mom gives me a six-foot-tall cardboard Chewbacca. He's holding his laser crossbow at his side, and his bandolier hangs from a shoulder across his chest. His wide mouth gapes in mid-honk, teeth bared, urging Han to hurry, no doubt. I put him to good use, propping him up behind Mom's bedroom door, in her closet, behind the shower curtain. She shrieks every time she opens her closet, closes her door, or tries to take a shower. This never gets old.

It's Saturday night, and Mom's folk dancing. She loves to dance. She developed her passion in Yugoslavia and Bulgaria while traveling as a student. Sometimes she drags us along, and I complain and roll my eyes, but, really, I think it's fun. Tonight she's on her own.

Elena and I settle into the couch belonging to a lady on our floor who baby-sits us on occasion. We've convinced her of the merit in watching $\mathrm{ABC}$ tonight. The Boat's hypnotic theme starts up, and 
we sit, transfixed. Soon into the episode, however, our eyes widen, our mouths open, and we edge forward and perch on the lip of the couch. There, interacting with Captain Stubing and the rest of the crew, is someone's idea of a little darling. They identify her as the Captain's daughter, but Elena and I can't believe we heard right. I stare at the screen, but I'm not taking in the storylines. A pug nose, freckles, white teeth, and that haircut - a cross between pageboy and Bay City Roller-consume me. Elena and I communicate our alarm without speaking, through shrugs and facial tics. Fantasy Island is a blur. We don't sleep well that night. We don't mention anything to Mom. We're afraid of what she might say.

The next time Elena and I see the Boat, the infernal apparition is gone. We don't get to watch the show every week, so it takes six or seven episodes, over the course of several months, before we allow ourselves to feel the relief. It's not the negation of a bad dream. We know it happened, that she exists, that she was on the show, but we're confident there must have been some mistake. After all, it wasn't his real daughter. She was the product of a girlfriend, not a wife. And surely the fact that she's gone bodes well?

I resume my imaginary life on the show.

The white decking flashes in the Caribbean sun, and I'm hot in my uniform. My sunglasses keep fogging up. I take them off, wipe them on my shirt, squint in the harsh glare. Captain Stubing strolls up and places a hand on my shoulder. He removes his hat and wipes his brow with a forearm. His bald pate twinkles in the sun.

"Son, I need you to do me a favor."

"Anything, Dad, just name it."

"When I was in the war, our PT boat went down in the South Pacific. My commander saved me from a shark and lost three fingers for his trouble. Anyway, his daughter's on board, and I just got word: he's fallen down an elevator shaft... he's dead."

"I didn't know you were in the war! Which war?"

"Never mind that now. The point is, I have shore business to attend to, and his daughter's pretty broken up. She needs looking after. Here she comes now."

Cheryl Ladd walks up in a hot pink bikini with a translucent blue sarong tied around her waist. Red and puffy skin surrounds her 
watery gray eyes. Flaxen scribbles of hair and silver tear trails on her cheeks glisten in the sun.

"Can I count on you to do this?" Dad asks, looking into my eyes.

I stand up straight and pull a salute. "Aye aye, Captain."

Our heads whip around at the sound of clattering deck chairs and the outraged exclamation of a sixty-year-old woman in a lime green kimono. Charo rushes up with a guitar under one arm and a chimpanzee under the other. "There you are!" she says, winking at me. "You promised me the afternoon!" The chimp's mouth opens and its lips pull back from its teeth. It screeches at me.

"I'm sorry," I say. "Duty calls. But I'd be happy to look after you tomorrow."

I stare at a recent picture of Whelan. I don't recognize my childhood nemesis, but I know she's in there, lurking beneath the mature features. This older Whelan seems to project success via a polished and practiced persona-professional hair and makeup, jewelry with a purpose, anything but casual clothes. Her eyebrows are a study in plucked perfection: smooth, sweeping, synthetic tildes. Despite this manufactured exterior, something's not right. She isn't smiling-her lips form a pursed, abject line. A jaded weariness sits in and around her eyes. She appears resigned, like she's going through the celebrity motions. This Whelan seems a far cry from the earnest, bouncy, we-can-do-it-if-we-only-try personality I loathed as a kid. I feel empathetic stirrings, but I catch myself. I don't want to give her up as a locus of blame.

I'm not sure exactly what I felt in Berkeley. Something operated on the edge of my emotional vision and intruded from the periphery during moments of sentient intensity. This encroaching perception fueled a visceral desire for escape, but not escape from Elena and my mom. I wanted to bring them with me. I wanted to soothe my sister. I wanted to make my mom happy. I wanted to fill the void that used to be my dad.

Mom dates a guy named Dale for a couple of months. I say "dates," but they don't go out much. Electric blue eyes act as counterpoint to his mid-length, light brown hair and the dark beard he keeps trimmed and short. He comes over in the evenings a couple times a week. Mom cooks and sometimes Dale messes around with my 
sister and me, colors in a book or plays cards with us. After dinner I badger him to build a card house or play a game of chess, but once he decides he's through, he sits there and ignores me as I ask questions and tug at his sleeve. Then he and Mom go in her room, and we hear her moaning, moaning, moaning to beat the band. At first it scares me, that moaning, but after the fourth or fifth time it just pisses me off. Elena stays scared. One night Dale and Mom come out of the bedroom and prance around naked. "What are you doing?" my sister asks, horrified. "Making love," Mom answers, arms akimbo, a wine glass in one hand. Dale laughs. Dark hair covers his entire body.

Sometimes, the next day, while playing hide-and-go-seek with my sister, or some other game, I end up by the black plastic trashcan Mom keeps in her room. Sometimes I look inside, and there's a yellow, slimy, knotted rubber sleeve, stuck to the white plastic liner, or sitting on top of opened envelopes. One time I poke at it with a finger and recoil from the slickness. I think, what are those things?

He doesn't last too long. One day he quits coming around. Mom doesn't leave her room for two days. The first night, after it becomes obvious she's not coming out, Elena and I creep up and listen at the bedroom door. We hear her sobbing and talking to herself. She says she doesn't want to live anymore. She repeats it over and over.

The next day Mom still hasn't emerged, and we don't know what to do. We play quietly in my room, but our hearts aren't in it. In the afternoon, we can't stand it and go to Mom's door again. We don't hear anything. We look at each other. A tangled mess of strawberry blond hair frames Elena's round face. There's a smudge of dirt on her freckled cheek. A white barrette has slid down its captive strands of hair and hangs crookedly at jaw level. Her brown eyes open wide and her chin wrinkles, like she's about to cry. I feel like crying, too. I knock softly.

"Mom?" I say. No answer. I open the door.

Mom sits in bed with her back against the wall and the blankets pulled up to her waist. She stares straight ahead through redrimmed eyes. Tear tracks gleam on her cheeks. Her white T-shirt is splotchy with damp patches. We shuffle to the bedside. She looks over, then opens her arms. We climb on the bed and she wraps us up, pulls us in, squeezes us hard enough to hurt. She starts crying again, violent sobs that wrack her body. We feel her chest heave 
and shake as breath sucks in and blows out in irregular jerks. "I'm sorry," she keeps repeating. My face presses against the burning skin of her neck. I feel hot tears dripping on my ear and cheek.

She loosens her grip after awhile, and Elena and I climb off the bed. I ask Mom if she wants anything. She doesn't answer, just brings her knees up and rests her head on them. I feel helpless, useless, worthless. We leave the room and shut the door. We go to bed. Elena sleeps in my room.

Mom's in the kitchen when we wake up. "Hi, you guys," she chirps. She fixes us French toast. She doesn't acknowledge the last two days and neither do we. Elena and I talk it over later, but we don't understand why Dale disappeared. We don't get that he's in his twenties, flunking out of grad school, into partying, into rock climbing, into getting on a nice piece of older tail, but not into this woman's two kids. One minute he's an intermittent, fuzzy presence in our lives, then he vanishes. Later on, I understand Dale. I think, if I ever see him again-you know, an improbable, chance meeting where the two people involved wrinkle their brows, cock their heads, and one of them, tentatively, says, "Dale?"-I think I might punch him in the throat.

Princess Cruises owes part of its success to The Love Boat, which provided initial and ongoing publicity for the company. Since 1998, Princess captains have married more than 1,00o couples in what is reportedly the original luxury liner seagoing nuptials program. In April 2004, Whelan collaborated in a promotional scheme with the shipping line by holding her second wedding aboard their newest and largest ship, the 116,000-ton Caribbean Princess. The ceremony occurred in Fort Lauderdale, Florida, a couple of days before the ship's maiden voyage. They broadcast it over the Web. The newlyweds spent their honeymoon on the inaugural cruise. Whelan invited several of the old cast members to the wedding. Gavin MacLeod, the Captain, attended. Whelan wore a light pink Mika Inatome gown, swathed in a fragile chiffon overlay and slathered with pearls and Swarovski crystals.

Mom never married a second time. She dated regularly into her fifties, even ended up in some long-term relationships, but they always crashed and burned. It didn't matter whether the men were assholes, philanderers, decent, or wonderful-she was incapable 
of believing they loved her. The relationships started out normal enough, but her neurotic paranoia would build, manifesting in accusations, hysterical outbursts, and scathing bouts of silence. Every man reached his breaking point and left, and she concluded that she'd been right: he didn't love her.

The infernal apparition returns to the Boat in the second week of November 1979. This time, she doesn't go away. She settles right in. She trots that look of consternation out for every episode-furrowed brow, watery eyes, mouth a small circle of dismay-but, by the end of each show, it's all sunshine and smiles. She's a cut-rate Shirley Temple in a blue and white uniform. She makes a mockery of our Thanksgiving.

I can't put a name to my feelings. I don't know the right words. "Forsaken," "vacuous," "revenge," and "homicide" lie outside the pale of my intelligence.

"I hope she falls overboard," I say, one Saturday night, three or four episodes into The Return.

"I hope she drowns," says six-year-old Elena.

Mom takes us to see the movie Airplane four times in two weeks. We employ wheedling tricks to effect these multiple viewings, but they're unnecessary, as she can't get enough of it, either. This is the funniest film we've ever seen (narrowly beating out Mel Brooks' Silent Movie). But two things detract from perfection. The first is that the infernal apparition is in the movie, and, what's worse, she's really funny. The second is Mom's laugh. It's one for the ages, perfect for raising the dead. It has several stages: first, she gasps out a mini-screech, just enough to empty her diaphragm; second, near silent heaves of laughter-each punctuated by a click at the back of her throat, the kind of sound you use to make a horse pay attention-precede the hic hic hiccupping of her breath drawing in, building up, swelling her dirigible-esque lungs; finally, the shrillest, most blood-curdling shriek rips from her soul, empties her body of air, and the process repeats...for two hours in this case. Elena and I hunch down in our seats and try to achieve invisibility while maintaining sightlines above the chair backs in front of us. It's a given that everyone in all six theaters can hear her. What we're wondering 
is how far the auditory assault reaches beyond the theater, into the city? What kind of a block radius are we talking about?

Years will have to pass, but this laugh will become one of the things I love most about my mom. I will get her going on purpose, especially in public, trying to kick start that irrevocable cycle. Her laugh is the purest expression of hilarity I've ever witnessed.

In 1981, Jill Whelan became Nancy Reagan's teen emissary in the Just Say No campaign. They traveled the country, decrying the use of drugs. Whelan attended state dinners. They helped lay the groundwork for George H. W. Bush's war on a class of inanimate objects. Whelan parlayed this and other experiences into fodder for her motivational speaking gigs. I wonder if she or Nancy knew of Lauren Tewes' cocaine addiction before it eventually resulted in Tewes leaving the show? I wonder if they pitched her? Just say no, Lauren-it's that simple.

BERKELEY, CALIFORNIA, NOVEMBER 4, 1980.

Mom, Elena, and I play cards in the evening after dinner. We switch up games, alternating between Crazy Eights, Go Fish, and Canasta. I stare out the sliding-glass door at the sky. It's the darkest blue it can get before turning black. I think I hear something, a rumble in the distance. It grows louder, a dull, rhythmic throbbing. Mom and Elena hear it, too. We get up. Mom slides open the glass door, and we're blasted by the staccato thunder of hundreds of marching feet slapping the pavement. The three of us crowd out on the balcony. Below us, an undulating mass of humanity heads for Telegraph. They take up the entire width of the street and stretch for blocks, a rolling human caterpillar roaring with one voice: HO! HO! HO! REAGAN'S GOT TO GO!

"I'm going down there!" I say.

"Oh no you're not," says Mom.

I look at her, trying to gauge her resolve. She raises her eyebrows and shakes her head. "No way." We stay on the balcony, waving at the protesters. It feels like hours before the last of them pass. The next day, in a bid against oppression, I get my coloring pens out and make bright, multi-colored "Fuck Reagan" signs. I hang them up all over the building. I know nothing about Reagan. 
Years later, I'll think I must have been prescient. Looking back at that moment on the balcony, I will think of Reagan with bolts on the sides of his neck. I will think of the villagers in Frankenstein and imagine pitchforks and torches in the marchers' hands. I will think of them as hippie shock troops on a righteous mission. I will think of them as doomed.

BERKELEY, CALIFORNIA, DECEMBER 9, 1980.

On the Ave, in the morning. The air caresses my face like a damp cloth and swirls of fog wrap around signposts, trees, and buildings. The entire area seems muted. I see several people sniffling on the street, wiping their noses and eyes with handkerchiefs. Cars pass by but none honk. They meander, listless, the sound of their motors cushioned by the fog. Something's not right. I'm listening to my Walkman, but every station plays nothing but the Beatles. I'm annoyed because there's a new Queen record out that I'm thinking about buying, and I want to hear the first single. There's a break in the music, and a DJ comes on. His voice shakes with genuine emotion. His "Hey, boys and girls, what's going on out there in radio land?" persona is shattered. He talks through tears. He tells the world that John Lennon's been shot and killed.

Adding insult to injury, Reagan survives his assassination attemptI hear more than one person on the Ave use this as an example in their arguments that life is cruel and perverse. I stand on the corner of Dwight and Telegraph, looking up the block, toward the university. Mom has admitted defeat. We're moving to southern California, to my grandmother's house in Redlands. We will live with her until Mom figures out what she's going to do about a career. I feel empty, the way I did when I realized my parents were splitting for good. Telegraph has become a living, breathing, soothing member of our family, and I don't want to leave it.

The July sun shines hot on my shoulders. People flit this way and that on the busy streets. A homeless man asks a man in a suit for change and follows him for half a block, talking to his back, after being refused. Squinting, I shade my eyes with my hand, trying to pick out Rasputin's up the block. I think about a last stroll through my favorite stores. I turn my back on the Ave and join Elena and Mom in moving boxes. 
The show outstayed its welcome. The producers tried some permutations over the last two years, shaking up the cast and such, but to no avail. Jill soldiered on to the bitter end. I wonder if she felt it slipping away? Did she pay attention to ratings? Could she feel the decline of the show's popularity as a palpable malaise, a malevolent, corrupting presence? Was there a point after which conversations stopped when she walked into auditions and Hollywood parties? Did other actors, directors, and producers start greeting her with clasped hands and concerned eyes, like undertakers? Did she recognize that as soon as Ted McGinley joined the crew in season eight the end was assured? (Did she know he was the living death knell of the sitcom, the prime-time apocalypse? Remember Happy Days? Not after he joined the cast you don't.) Or was she too insulated in the cocoon of her early success?

Her initial, meteoric rise didn't translate into a lifelong, vibrant acting career. At a certain point, the good gigs dried up. Considered a B-list celebrity by the end of the ' 8 os, she personified and cemented that identity by doing infomercials and anemic Love Boat reunion shows in the '9os. Her stint on E! Star Dates in 2002 didn't help, either. Between acting gigs she worked as a production coordinator of live events and pursued a career in broadcast journalism. True to her conservative roots, she ended up a news writer/producer on a station owned by Fox. She forayed into junk jewelry. She raised her son. She continued to land the occasional acting job.

I wonder if she ever hangs out alone, drinking wine maybe, sitting in a comfortable recliner in front of the TV, playing Love Boat episodes. Maybe she mouths certain passages of dialogue, occasional tears leaking from her eyes when the nostalgia becomes too profound. Perhaps she stops to rewind especially favorite moments: an exchange with Dick Van Patten, a smile from Richard Hatch, a hug from Paul Williams. I wonder if she ever contemplates what went wrong with her career. Maybe she doesn't consider her career something that went wrong. Maybe she never thinks about it. Maybe she's content. 